\title{
Recent trends in Australian local government reform
}

\section{Graham Sansom}

Institute for Public Policy and Governance

University of Technology Sydney

Australia

Email: Graham.Sansom@uts.edu.au

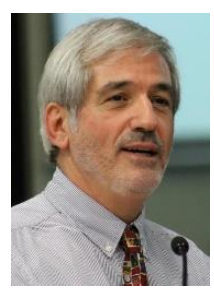

"As both a cause and consequence of its changing role in society, it seems that the local government sector in Australia is almost permanently under the microscope" (Grimsey et al. 2012, p. 10).

\section{Context}

Nearly a decade ago the then Australian Centre of Excellence for Local Government (ACELG) published two overviews of local government reform across Australia during the period 2000-2013 (ACELG 2011; Gooding 2013). The two papers described a broad - some might say bewildering array of moves to bring about desired changes in the roles, structures, operations and governance of municipalities. Gooding (2013, pp. 46-47) identified 25 initiatives either underway or about to commence in jurisdictions across Australia. He defined 'local government reform' as “a wide variety of inquiries, reviews and change processes, proposed or implemented [which] share an intention to improve some aspect of the structure, performance or accountability of local government [but] can take different and sometimes even contradictory directions" (Gooding 2013, p. 3).

Australia is a federation of six sovereign states (former British colonies) and two largely self-governing territories. One of those two, the Australian Capital Territory (Canberra), is effectively a city-state without municipalities. Elsewhere, local government is established and regulated under state and Northern Territory legislation (Sansom 2009), giving rise to considerable diversity from one jurisdiction to another in perceptions of 'problems' in local governance and the 'solutions' deemed appropriate. Hence numerous issues and ideas around potential changes or improvements may be canvassed at any one time. And while it has no constitutional relationship with local government, the federal government

DOI: https://doi.org/10.5130/cjlg.vi23.7546

Article History: Received 16/12/20; Accepted 21/12/20; Published 23/12/20

Citation: Commonwealth Journal of Local Governance 2020, 23: 7546, https://doi.org/10.5130/cjlg.vi23.7546

(C) 2020 Graham Sansom. This is an Open Access article distributed under the terms of the Creative Commons Attribution 4.0 Unported (CC BY 4.0) License (https://creativecommons.org/licenses/by/4.0/), allowing third parties to copy and redistribute the material in any medium or format and to remix, transform, and build upon the material for any purpose, even commercially, provided the original work is properly cited and states its license. 
sometimes adds to the mix because it has become the major provider of untied grants to municipalities and involves itself in local affairs through numerous special-purpose funding programmes. ${ }^{1}$

The performance of Australian local government is therefore closely scrutinised, and state governments ${ }^{2}$ can intervene whenever they see fit to bring about regulatory, structural, financial or operational change. They tend to react swiftly and often with ad hoc responses to real or perceived failings, notably in corporate or financial governance, probity and councillor conduct. During recent decades most have also commissioned wide-ranging reviews of the sector, with a particular focus on structures, funding and financial management, and legislation.

Another contributing factor to perceptions of the need for reform are ongoing pressures for change in local government's role as part of the federal system of government. Although the sector only accounts for about $5 \%$ of total public sector expenditure, those municipalities that command substantial resources can make a decisive contribution to state and federal programmes and a real difference to local outcomes. The states can 'control' local government as an institution, but they cannot prevent shifts in the economy, society and environment that demand local responses and that generate new or different community needs and expectations. Nor, having legislated the establishment of democratically elected local councils, can they completely ignore or overrule the 'will of the people' or control evolving relationships between those councils and their constituents.

\section{Six themes}

Against that background this paper provides a partial update of the findings of ACELG (2011) and Gooding (2013) by considering more recent developments under six thematic headings: structural reform and regional cooperation; principles-based local government acts; roles and responsibilities of elected officials;; revenue controls; financial and performance auditing; and integrity and accountability. The coverage is highly selective and seeks to identify significant trends rather than explore every initiative taken over the past decade or currently proposed.

\section{Structural reform and regional cooperation}

From the early 1990s until 2016 forced or 'semi-voluntary' municipal mergers and boundary changes were a centrepiece of local government reform in all states, with the sole exception of Western Australia. ${ }^{3}$ At present, however, there appears to be little or no appetite to proceed further down that path, despite evidence of 'unfinished business' in several states and occasional calls from business

\footnotetext{
${ }^{1}$ During its early years last federal Labor government (2007-13) funded a suite of local government reforms, but that initiative petered out after 2010 and whilst it continues to engage with municipalities and has generally maintained the level of financial support, the current Liberal-National coalition sees the performance of local government almost entirely as a matter for the states.

${ }^{2}$ Throughout the remainder of this article the term 'state' includes the Northern Territory.

${ }^{3}$ For a broad outline of this history see Dollery et al. (2012, pp. 15-45).
} 
groups for renewed action. One explanation is the complete or partial failure of recent merger programmes in Western Australia (WA) and New South Wales (NSW).

The WA government embarked on a major reorganisation of local government in metropolitan Perth in 2011, following a failed attempt to promote voluntary mergers throughout the state (Metropolitan Local Government Review 2012). In mid-2013 it announced proposals to reduce the number of metropolitan municipalities from 30 to 14 (later increased to 17), largely through forced amalgamations. But three of the proposals required community approval through local referenda, all of which were lost, and the government then abandoned the whole programme.

In NSW 'preferred options' for mergers affecting around half of the state's local government areas were identified by the Independent Local Government Review Panel (2013). After a complex process and long delays, in late 2015 the government finally announced quite different plans for forced amalgamations involving 75 municipalities and proceeded immediately with implementation. However, following intense opposition, legal challenges, a lost by-election and a change of state premier, the process was abandoned in early 2017 when only two-thirds complete.

Both states have since turned their attention to strengthening regional cooperation between municipalities, as well as collaboration at a regional level between local government and state agencies. In 2017 the NSW parliament passed amendments to the Local Government Act to create regional 'Joint Organisations' (JO) comprising representatives of member municipalities, with observers from state agencies also attending meetings as required. The principal aim is to set agreed regional priorities and create a stronger 'regional voice', but JOs are essentially free to expand their activities as determined by their members. However, it appears that in most regions progress has been slow.

In Western Australia a recent report by the Local Government Review Panel (2020, pp. 19-20, 31-33) saw greatly expanded regional cooperation as a core element of the proposed new Local Government Act. It favoured:

- Making increased collaboration a specific objective and operational principle of the Act (following the example of Victoria)

- Requiring regional cooperation between municipalities when they prepare strategic and corporate plans

- A flexible model of 'Joint Subsidiaries' for use by groups of municipalities in strategic planning, resource sharing, cooperative service delivery and commercial enterprises

- Possible establishment of collaborative 'regional authorities' that could bring together local government, state and federal agencies, and other parties to address complex regional issues, such as provision of services to remote Aboriginal communities. 
Another potentially significant development in regional cooperation has occurred in Tasmania, where a Greater Hobart Act was passed in August 2019. The goal is to foster coordination amongst four large municipalities and key state agencies to improve strategic planning, infrastructure provision and use, and community health and wellbeing across the capital city region. A Greater Hobart Committee will comprise the four mayors together with the state ministers for economic development, infrastructure, housing and community development. The Committee will establish an agreed work programme covering strategic planning, transport, community facilities, affordable housing and urban renewal. It will be supported by an advisory group of senior officials from both local and state governments. However, implementation of the Act is yet to get under way.

\section{Principles-based local government acts}

Wide-ranging reviews of local government acts have taken place in Queensland (2012), New South Wales (2012-17), Victoria (2015-20), South Australia (2019-20), Tasmania (2018-continuing) and Western Australia (2017-continuing). In the cases of NSW, Victoria and Western Australia, those reviews were intended to result in completely 'new' acts, but in NSW only substantial amendments were enacted in 2016 and 2017, and in Western Australia only 'priority reforms' for governance and accountability have been completed to date. Victoria finally adopted a largely re-written act in March 2020. Elsewhere expectations appear limited to packages of amendments.

A common feature of the revised acts has been a move (or an intention to move) from detailed prescription of municipal operations to a 'principles-based' approach. This would complement the 'power of general competence' now available in various forms to municipalities across Australia. ${ }^{4}$ Recently updated acts include a set of principles that indicate in broad terms how municipalities should discharge their role and functions, conduct their affairs and provide good governance for their communities. These overarching principles may be supplemented by more detailed guidance on specific functions or responsibilities, such as decision-making, financial management, strategic and corporate planning, service delivery, and community engagement.

Whether this approach will actually result in less detailed prescription remains to be seen. For many years state governments have tended to make frequent amendments and additions to local government acts. These are often ad hoc responses to issues and problems that inevitably arise in any complex system of governance. Moreover, ministers may make supplementary Regulations, with only limited

\footnotetext{
${ }^{4}$ In Victoria, for example, section 10 of the Local Government Act 2020 provides that: "Subject to any limitations or restrictions imposed by or under this Act or any other Act, a Council has the power to do all things necessary or convenient to be done in connection with the performance of its role ... The generality of this section is not limited by the conferring of specific powers by or under this Act or any other Act."
} 
parliamentary scrutiny, to add flesh to the bones of the act itself. It seems unlikely that the states will resist the political pressures or temptation to meddle in the future.

\section{Roles and responsibilities of elected officials}

Another common feature of recent amendments to local government acts has been changes to the description of the roles and responsibilities of mayors and councillors. Since the 1980s Australian local government has been characterised by a 'managerialist' framework with only a small number of elected councillors. They are expected to operate as a 'board of directors', focusing on strategic and policy issues and leaving day-to-day management of the organisation in the hands of the chief executive. This remains the underlying philosophy except to some extent in Queensland, where popularly elected mayors may exercise a measure of executive authority, especially in the City of Brisbane and other large urban centres (Sansom 2016).

However, several states have passed amendments (or are considering proposals) to clarify roles and responsibilities in a way that reinforces the democratic prerogatives and obligations of elected officials, and as a consequence shifts the balance of power somewhat away from management. NSW offers perhaps the best example of this. In 2016 the statements of roles and responsibilities were extensively revised by a series of amendments to the NSW Local Government Act 1993 along the following lines:

- A new set of responsibilities for the 'governing body' - the councillors collectively - that highlights its pre-eminence in policy, strategic and corporate planning, and keeping the performance of the organisation under review (section 223)

- An expanded leadership role for the mayor in policy and planning (including ensuring effective implementation), community engagement and providing advice and 'strategic direction' to the chief executive (section 226)

- A specific role for individual councillors in facilitating communication between the local community and the governing body (section 232)

- A cooperative relationship between the chief executive and the mayor and governing body, in which the chief executive must provide timely information and advice, assist the mayor and councillors in carrying out their responsibilities, and manage the organisation in accordance with the governing body's plans and policies (section 335).

\section{Revenue controls}

All Australian states impose limits of some sort on the way local governments raise revenue. At the macro level, municipalities are confined to just one tax - property 'rates' - plus a range of fees and charges. But in addition, specific controls prevent them from fully realising the potential of those revenue sources. The most significant is the practice of 'rate-pegging' or 'rate-capping', under which states restrict local government's access to increased revenue that could otherwise flow from growth in 
the number and value of properties. NSW has had a system of rate-pegging for more than 40 years: municipalities must justify proposed increases above a set level by making a detailed case to, and receiving approval from, the state's pricing authority. The consequence is that rates per capita in NSW are substantially lower than in other states, and inquiries have indicated that local governments are struggling to meet community needs and expectations (NSW Productivity Commission 2020).

Victoria imposed a similar arrangement for several years in the late 1990s. It was abandoned following a change of government in 1999, but reintroduced in 2016. The Victorian Local Government Act already included a provision that enabled the responsible minister to intervene if a particular municipality imposed what he or she considered to be excessive increases in rates, but seemingly as a populist measure the government decided to replace that provision with much more complex and costly universal rate-capping.

In South Australia the state government sought to introduce universal rate-capping in 2018, but its Bill was voted down in the parliament's upper house. Following a second failed attempt and lengthy negotiations with the local government association, the government recently settled on a modified approach under which the state's Essential Services Commission (ESC) will undertake regular reviews of each municipality's long-term financial, infrastructure and asset management plans, as well as proposed revenue sources to be outlined in new ten-year funding plans. The ESC will then publicly advise the municipality on (among other things) whether the imposition of rates is 'appropriate'. Technically this scheme falls short of 'rate-capping', but in practice the level of public scrutiny and hence political risk that elected councils will face may well produce much the same outcomes. Moreover, the scope of ESC reviews may be expanded in future by means of Regulations. ${ }^{5}$

By contrast, the Tasmanian government has abandoned proposals for oversight of rates increases by its pricing authority. ${ }^{6}$ Instead, the independent chairs of municipal Audit Panels will be required to review any proposals to levy rates that deviate from the local government's long-term financial plan, and/or any changes to that plan. This may represent an interesting move towards increased local accountability and self-regulation. The WA Local Government Review Panel (2020, p. 40) has also pointed to the scope for independent audit committees to play a similar role, the state government having ruled out centralised rate-capping.

\section{Financial and performance auditing}

The past decade has witnessed a renewed focus on financial and performance auditing, including both external and internal audits. NSW and Western Australia joined the other states, except South Australia, in making their state Auditors General responsible for conducting (or commissioning) both financial

\footnotetext{
${ }^{5}$ See https://dpti.sa.gov.au/local_govt/local_government_reform

${ }^{6}$ See http://www.dpac.tas.gov.au/divisions/local_government/local_government_legislation_review
} 
and performance audits of local government. Financial audits are carried out for individual municipalities, but the results are typically aggregated to provide state parliaments with an annual summary of the financial position of local government as a sector, and to identify key issues and trends. Auditors General report directly to parliaments, so their published findings can be very helpful in drawing attention to financial concerns for local government that state governments might prefer to ignore or downplay.

Performance audits by Auditors General are usually sector-wide, examining overarching issues such as procurement, service delivery or community engagement by means of surveys and case studies. Again, these audits may delve into issues that might otherwise be neglected by local and state governments, and may make uncomfortable findings about the need for improvement.

Requirements for internal audit and the role of audit committees have also been strengthened in several jurisdictions, notably NSW, Victoria and South Australia (Centium 2020). There is a clear trend towards requiring municipalities, singly or in regional groups, to establish 'expert' audit committees that have a majority of independent members (that is, people other than councillors or municipal managers) and an independent chair. At the same time, the remit of audit committees is expanding beyond the traditional areas of financial oversight, risk and probity into strategic and corporate planning, services, organisation performance and continuous improvement. In NSW the committees have been renamed 'Audit, Risk and Improvement' to reflect their broader scope.

What seems to be evolving is a distinctive approach to internal audit in local government that addresses the performance and accountability of municipalities as democratic, elected bodies serving local communities - a quite different context from that of the private sector and government agencies. This evolution is highlighted by the ideas emerging from Tasmania and Western Australia about the potential for independent audit committees to provide assurance to local communities - and state governments that municipalities are 'doing the right thing'.

\section{Integrity and accountability}

There is a widespread perception across Australia that local government is prone to misconduct, fraud, corruption and poor financial management (Wilson et al. 2019). Real or perceived failings attract considerable attention and calls for increased scrutiny, regulation and intervention by state agencies, ombudsmen and corruption commissions. To some extent concerns about the way municipalities conduct their affairs are magnified by requirements for nearly all decisions to be made in public, revealing inevitable tensions amongst councillors and weaknesses in decision-making processes. In addition, the application of complex codes of conduct creates numerous opportunities to find fault. Nevertheless, from time to time public inquiries reveal sufficient examples of unacceptable 
(occasionally criminal) conduct that warrant further action to ensure required standards of probity and trust.

Over recent years state governments have given a very high priority to implementing those additional or improved measures recommended by inquiries or otherwise considered essential. In addition to the strengthening of internal audits mentioned earlier, most states have updated codes of conduct and legislative provisions covering conflicts of interest, fraud and misconduct. Queensland and Victoria have revamped their mechanisms for handling and determining public complaints concerning the conduct of councillors and senior managers, and both South Australia and Western Australia are set to follow suit. As well, some states have introduced additional measures for ministers to dismiss individual councillors found guilty of serious misconduct, and for early intervention in municipalities where the standard of governance is considered unsatisfactory. On a more positive note, several states are looking to increase requirements and expand opportunities for councillor training.

\section{Commentary}

The past decade has seen a continuation of the unrelenting local government reform agenda observed by Grimsey et al. (2012), and this paper has covered only a few key elements. However, by way of concluding, two overarching issues may be identified.

Firstly, the evident move away from a focus on structural reform may well have wider significance. The two major reports that underpinned the amalgamation proposals for Perth and NSW (but were largely ignored when it came to implementation) expressed an expansive view of the role of municipalities as democratic representatives of local communities and partners in the broader system of government. Their recommendations for structural reform were couched in those terms. However, the respective state governments adopted a narrower outlook that saw larger municipalities doing much the same as their predecessors, just more efficiently and effectively. And as outlined in earlier sections of this paper, many of the subsequent reforms across Australia have concentrated on the detail of ensuring 'good governance' in local government, often entailing additional mechanisms for oversight and intervention. At the same time, the federal government largely appears to have lost interest in the potential of local government as a strategic partner, even though it continues to channel substantial sums of money to and through municipalities and their regional organisations. This apparent loss of interest (or failure to understand the possibilities?) was reflected in the recent exclusion of the Australian Local Government Association (ALGA) from the new 'National Cabinet' that has replaced the former Council of Australian Governments, of which ALGA had been a member since its inception in 1992.

Secondly, more questions need to be asked - and answered - about whether the states and local government have sufficient resources to make sure that all the reform initiatives can be effectively articulated and implemented in a timely manner, and whether the desired outcomes are being achieved. 
There are surely lessons to be learned from the fact that it took five years to complete the new Victorian Local Government Act, with a major implementation programme now to be rolled out over several more; that NSW abandoned its attempt to produce a new act; and that after three years Western Australia has yet to fully implement the first stage of its review, with stage two drafting having only just begun. Similarly, reforms to internal audit processes in NSW are yet to commence four years after the required legislation was passed: they are expected to take another six to eight years to implement fully. Meanwhile, Queensland's reform of arrangements for processing complaints about councillor conduct in 2018 has resulted in an unexpected surge in complaints necessitating considerable additional resources for the new Office of the Independent Assessor. And so on.

Turning to outcomes, the effectiveness or otherwise of municipal mergers and boundary changes in achieving their objectives has been subject to intense scrutiny, chiefly through academic studies and reports commissioned by opponents (Dollery et al. 2012). However, there has been very little - if any - evaluation of the raft of 'good governance' reforms. Are the elaborate codes of conduct and complaints and disciplinary procedures actually reducing misconduct? Are audit committees performing an effective role? Are controls over municipal revenue-raising really leading to improved financial management, more efficient operations and meaningful savings for households; or are they gratuitously denying an important part of the public sector much needed funds to provide essential services and infrastructure? In these and other cases, the answers are mostly unknown.

Of course, local government, like its state and federal counterparts, should seek continuous improvement, and there is undoubtedly much to be done. However, one person's 'reform' may be another's unwarranted distraction and expense. Moreover, as Gooding (2013) pointed out, some of the measures taken may contradict others. 'Reform' is meant to entail improvement. It remains to be seen whether the reforms of the past decade have indeed tackled the key issues and priorities in a cohesive way and will thus achieve meaningful gains.

\section{Declaration of conflicting interest}

The author declared no potential conflicts of interest with respect to the research, authorship, and/or publication of this article.

\section{Funding}

The authors received no financial support for the research, authorship, and/or publication of this article.

\section{References}

Australian Centre of Excellence for Local Government. (ACELG) (2011) Unfinished business? A decade of inquiries into Australian local government. University of Technology Sydney. Available at: https://opus.lib.uts.edu.au/handle/10453/42084

Centium. (2020) How local government can maximise the benefits of internal audit. Available at: https://centium.com.au/news/how-local-government-can-maximise-the-benefits-of-internal-audit/ 
Dollery, B., Grant, B. and Kortt, M. (2012) Councils in cooperation: Shared services and Australian local government. Sydney: The Federation Press.

Gooding, A. (2013) Review of current local government reform processes in Australia and New Zealand. Australian Centre of Excellence for Local Government. Sydney: University of Technology Sydney. Available at: https://opus.lib.uts.edu.au/handle/10453/42147

Grimsey, D., Jones, B.C. and Hemingway, G. (2012) Strong foundations for sustainable local infrastructure. Melbourne: Ernst and Young. Available at http://vccia.com.au/sites/default/files/201702/Ernst\%20Young\%20Report\%20June12.compressed.pdf

Independent Local Government Review Panel. (2013) Revitalising local government: Final report. Sydney, October. Available at https://www.northsydney.nsw.gov.au/files/assets/public/docs/1_council_meetings/have_your_say/final_r eport_-_local_government_review_panel_oct_2013.pdf

Local Government Review Panel. (2020) Final Report: Recommendations for a new local government act for Western Australia. Government of Western Australia. Available at: https://www.dlgsc.wa.gov.au/docs/default-source/local-government/local-government-review-panelfinal-report.pdf?sfvrsn=acefce14_1

Metropolitan Local Government Review. (2012) Final report of the independent panel. Perth, July. Available at https://www.parliament.wa.gov.au/publications/tabledpapers.nsf/displaypaper/3815506ab06573e0bcb5ff bb48257aa300037750/\$file/5506.pdf

NSW Productivity Commission. (2020) Review of infrastructure contributions in New South Wales: Final report. Available at http://productivity.nsw.gov.au/sites/default/files/202012/Final\%20Infrastructure\%20Contributions\%20Review\%20Report.pdf

Sansom, G. (2009) Commonwealth of Australia. In: Steytler, N. (ed.) Local government and metropolitan regions in federal systems (A Global Dialogue on Federalism Vol 6), (pp. 8-36). McGill-Queen's University Press, Montreal and Kingston, for the Forum of Federations.

Sansom, G. (2016) Reframing the role of Australian mayors: An update and rejoinder to Grant, Dollery and Kortt. Local Government Studies, 42 (6), 1047-1059. https://doi.org/10.1080/03003930.2016.1228564

Victorian Government (2020) Local Government Act 2020 (Vic) Available at: https://www.legislation.vic.gov.au/as-made/acts/local-government-act-2020

Wilson, S., Pallant, J., Bednall, T. and Gray, S. (2019) Australian leadership index:2019 national survey report. Swinburne University of Technology. Available at: https://www.australianleadershipindex.org 